\title{
A comunicação, a recepção e o consumo enquanto práticas culturais: um novo olhar
}

\author{
Maria Amélia Paiva Abrão \\ Mestre em Comunicação pelo Mestrado em Comunicação e Práticas de Consumo da ESPM e \\ especialista em marketing pelo MBA Executivo da ESPM. \\ E-mail: amelia.abrao@gmail.com
}

Resumo: A sociedade contemporânea, que tem sido denominada sociedade de consumo, caracteriza-se pelas constantes e permanentes mudanças, aceleradas pelo avanço da tecnologia. As relações comunicação/recepção/consumo, uma das características dessa época, estão manifestadas na sociedade como um todo. Este artigo considera que os aspectos materiais e simbólicos dos bens estão intrinsecamente interligados: todo produto possui um significado que lhe é atribuído socialmente e uma face concreta - o objeto per se stante não possui valor enquanto não for socialmente utilizado.

Palavras-chave: Consumo, recepção, comunicação, telenovela, rituais.
Abstract: Contemporary society, often called consumer society, is characterized by constant and permanent transformations, accelerated by technology's advancement. The relationship among communication/ reception/consumption, characteristic of our era, manifests itself in society as a whole. We considered that the symbolic and material aspects of the product are intrinsically connected: every product has a significance that is socially attributed and a concrete side - the object per se stante does not have a value while it is not utilized by society.

Keywords: Consumption, reception, identity, soap opera, rituals.

Estudar o consumo é importante, pois por meio deste ocorre a apropriação dos produtos sociais, ou seja, o consumo é social, através dele podemos identificar dinâmicas culturais e sociais.

Porém, antes de entrarmos neste assunto, é necessário deixarmos de lado todas as concepções reducionistas sobre consumo. O primeiro estereótipo é o que identifica o consumo com o puro consumismo, ação desenfreada de comprar. Não que este não exista, mas não é o nosso foco de pesquisa, como também não acreditamos que seja pertinente ao campo da Comunicação. Trata-se de tema dos estudos das ciências comportamentais. $\mathrm{O}$ consumo também não deve ser visto apenas como estratégia mercadológica, assunto de grande interesse ao campo da Administração. O que propomos estudar está muito além dessas concepções, está ligado à cultura, à nossa vida cotidiana. 
1. GARCÍA CANCLINI, Néstor. Consumidores e cidadãos: conflitos multiculturais da globalização. Tradução de Maurício Santana Dias e Javier Rapp. 4. ed. Rio de Janeiro: Editora UFRJ, 1999. p. 77.

2. MCCRACKEN, Grant. Cultura e consumo: novas abordagens ao caráter simbólico dos bens e das atividades de consumo. Tradução de Fernando Eugênio. Rio de Janeiro: Mauad, 2003. p. 30.

3. MARX, Karl. Para a crítica da economia política. São Paulo: Abril Cultural, 1982. p. 9.

4. Ibid. comunicação \& educação • Ano XVI • número 1 • jan/jun 2011

Os Estudos Culturais nos mostram a importância em estudar a cultura de forma abrangente, percebendo que esta ocorre no cotidiano de uma sociedade, ou seja, é na vida cotidiana que significados são elaborados e transformados e é a partir dela que surgem novos movimentos que formam a cultura de uma sociedade. Sendo assim, a cultura é dinâmica, feita pelos/para os povos.

É nessa vida cotidiana, em que a cultura está em constante transformação, que estão inseridos diversos objetos. No entanto, um produto por si só não significa nada. O que queremos dizer é que o produto só adquire significado a partir das relações sociais que ocorrem no cotidiano de cada sociedade, isto é, "o consumo é um conjunto de processos socioculturais em que se realizam a apropriação e os usos do produto". Em outras palavras, o consumo é constitutivo do ser humano enquanto ser social.

Enganam-se os que pensam que esta visão do consumo é resultado da sociedade de consumo em que vivemos atualmente. Se olharmos para trás veremos que o consumo esteve presente em todas as civilizações. É claro que, com as novas tecnologias e facilidades de acesso, temos hoje uma gama de produtos e serviços muito maiores que no séc. XVII, por exemplo. McCracken² nos mostra que neste período o consumo já se inseria nas práticas sociais, era utilizado como forma de diferenciação: através das cores das roupas os aristocratas da era elizabethana se distinguiam dos demais.

\section{PRODUÇÃO, CONSUMO E NECESSIDADE}

Marx já dizia que produção e consumo são a mesma coisa, ou seja, para falar de consumo é necessário conhecer a produção. A produção emerge a partir dos indivíduos sociais de uma determinada época, o mesmo acontece com o consumo.

$\mathrm{Na}$ produção, os membros da sociedade apropriam-se dos produtos da natureza para as necessidades humanas; [...] no consumo, os produtos convertem-se em objetos de desfrute, de apropriação individual. [...] convertendo-se diretamente em objeto e servidor de necessidade ${ }^{3}$.

A partir do consumo de um produto é que ocorrerá uma nova produção, ou seja, se o produto não for consumido não haverá produção. Marx afirma que a necessidade cria a produção, bem como esta cria aquela. Dessa forma, necessidade, produção e consumo estão intimamente interligados. Nas palavras de Marx, "[...] a produção não cria somente um objeto para o sujeito, mas também um sujeito para o objeto".

Devemos ressaltar que as necessidades não são meramente fisiológicas ou, como alguns dizem, básicas. Toda e qualquer necessidade é formada no seio da sociedade. A vontade de matar a fome com sushi ou com um pão amanteigado está de acordo com o meio social em que vive o sujeito. Sendo assim, não existem necessidades básicas, pois toda e qualquer necessidade é social. Nas palavras de Slater, "vivenciamos todas as necessidades (inclusive as 


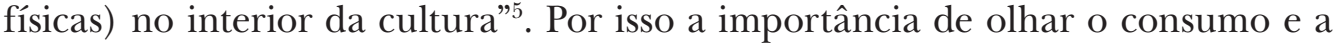
produção de um determinado bem localizado em uma dada sociedade e num determinado tempo. Se assim não o fizermos, os resultados de nossa pesquisa serão inconclusivos.

\section{RELAÇÕES ENTRE COMUNICAÇÃO, RECEPÇÃO E CONSUMO}

Os Estudos de Recepção nos mostram que o processo de comunicação é complexo, envolve mais do que emissor e receptor em conjunto e é no cotidiano que ocorre o diálogo. O consumo também é um processo complexo (cultural e social) que se desenvolve nesta mesma vida cotidiana.

Se tanto a comunicação quanto o consumo emergem das relações sociais que ocorrem no interior de uma sociedade, em seu dia a dia, podemos dizer que ambos são parte integrante de uma mesma cultura. Sendo assim, não há como diferenciar receptor de consumidor, ambos são a mesma pessoa, isto é, o mesmo sujeito que recebe uma mensagem da mídia é também um consumidor dentro de sua sociedade. Em suma, estudar o consumidor é estudar o receptor e vice-versa; é estudar como esse sujeito se desenvolve em sua cultura e como ambos se transformam a partir de suas relações sociais com outros sujeitos.

O consumidor não é um homem isolado, não é um mero repetidor de valores e escolhas. Ele é membro ativo da sociedade em que vive, nos limites de cuja estrutura terá opções. Trata-se do sujeito ativo, mesmo conceito presente nos estudos de recepção, ou seja, são os mesmos sujeitos que vão formar o consumo ativo. E que, sendo ativo, o consumo não é apenas consumismo, no sentido que o senso popular atribui a essa palavra ${ }^{6}$.

Ao ser inserido em um determinado contexto cultural, o produto absorve os significados que circulam nessa instância. Dessa forma, "as propriedades conhecidas do mundo passam assim a residir nas propriedades desconhecidas do bem de consumo"7. Lembrando que para um produto ser reconhecido pelos receptores/consumidores, bem como os significados atribuídos a ele, é necessário que se insira em um determinado contexto sociocultural. Um objeto utilizado no Brasil pode não possuir o mesmo significado e/ou utilidade em um país como a Índia, pois cada país possui suas peculiaridades, seus valores, suas tradições, que conduzirão os significados e os valores de troca atribuídos a este bem. Portanto, ao dizermos "que todo consumo é cultural, também estamos dizendo que todos os objetos são culturalmente significativos e que, na verdade, nenhum objeto pode ser simplesmente funcional"8.

Consumo e cultura estão intrinsecamente interligados, da mesma forma que comunicação e cultura, consumo e recepção, e, portanto, comunicação e consumo. Ao estudarmos a relação comunicação/consumo estamos procurando entender a cultura de uma determinada sociedade, como esta opera, quais são os modos de vida, tradições, identidades que circulam em um determinado
5. SLATER, Don. Cultura do consumo \& modernidade. Tradução de Dinah de Abreu Azevedo. São Paulo: Nobel, 2002. p. 132

6. BACCEGA, Maria Aparecida. Inter-relações comunicação e consumo na trama cultural: o papel do sujeito ativo. Animus: revista do Programa de Pós-Graduação da UFSM, v. 15, p. 4, 2009. Disponível em: <http://w3.ufsm.br/ animus/animus_2009-1_ art06.html>. Acesso em: 8 out. 2010.

7. MCCRACKEN, op. cit., p. 107.

8. SLATER, op. cit., p. 135. 
momento. Como diria Alonso, "o comportamento do consumidor pode ser considerado como um bom instrumento de diagnóstico para compreender a estrutura da sociedade em um determinado momento e para antecipar suas possíveis evoluções"9.

Ao estudarmos os consumidores estamos estudando também os receptores, pois recepção e consumo não se separam. Os receptores são os próprios consumidores, que recebem as mensagens e as interpretam de acordo com suas práticas sociais, com suas vivências, e as reelaboram atribuindo-lhes novos significados.

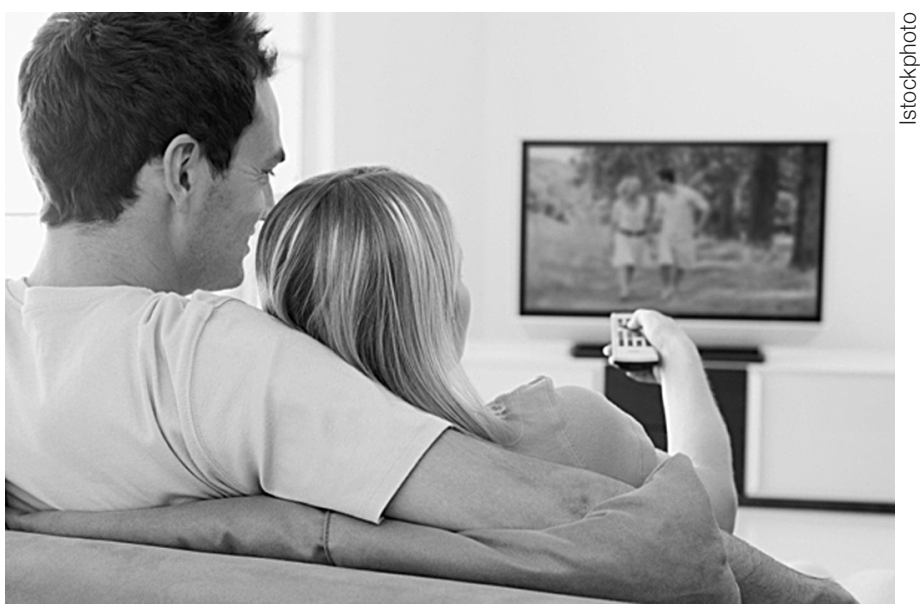

Ao estudarmos os consumidores, estamos estudando também os receptores. São estes receptores que irão consumir determinados produtos e/ou serviços, escolhendo-os de acordo com suas identidades, com os grupos aos quais pertencem. Em suma, "a pessoa que compra um produto ou recebe um impacto publicitário é a mesma pessoa que trabalha, lê, vota ou se preocupa com a sua velhice. Seria, pois, errôneo isolar a atividade específica de consumo e fazer dela uma espécie de abstração"10.

\section{CONSUMO: APROPRIAÇÃO E USO DOS BENS}

Como vimos, sentidos são produzidos através do consumo, ou seja, é a partir dos usos dos produtos que os significados serão construídos em uma cultura. Estes significados podem ser transformados ou trocados no decorrer do tempo, uma vez que a cultura é dinâmica, está sempre se reformulando.

Ao existir nos bens, a cultura passa a ser vivida em toda parte no mundo material. Para qualquer lugar que se olhe, em qualquer coisa feita pelo homem que se toque, tudo o que se vê é formulado de acordo com categorias e princípios culturais. Nos bens, a cultura se ubíqua ${ }^{11}$.

A mudança do valor simbólico de um produto pode ocorrer para que este continue a legitimar um determinado grupo ou classe social, como também ocorre para que o produto passe a pertencer a outro grupo, perdendo as características que eram peculiares ao antigo grupo. Como exemplo, podemos citar as sandálias Havaianas que, até a década de 1980, eram vistas como um produto das classes mais baixas. Com o passar do tempo seu significado foi se transformando e hoje elas são utilizadas por pessoas da classe alta, inclusive por top models como Gisele Bündchen. Podemos dizer que o consumo promove 
uma conexão entre as pessoas; estas consomem para pertencer a um determinado grupo e para se distinguir de outros.

Não podemos nos esquecer do conceito de hegemonia de Gramsci, segundo o qual o grupo hegemônico opera por consenso para se manter no poder. Através de determinados produtos, certos valores do grupo dominante são reforçados, muitas vezes de forma naturalizada, isto é, sem que a maioria perceba, são naturalizados. Da mesma forma, o consumo também pode ser utilizado como forma de protesto. Através da utilização de certos bens as pessoas podem mostrar sua indignação ou revolta perante o sistema dominante. Podemos aqui citar os hippies e os punks, que passaram a utilizar determinados produtos como protesto. Não demorou muito para que o grupo hegemônico, principalmente através da mídia e da moda, se apropriasse dos significados dados aos produtos utilizados por aqueles grupos, reformulando-os e devolvendo-os à sociedade com os significados neutralizados.

Os significados atribuídos a um bem ocorrem a partir de seu uso social. Um mesmo produto pode ter diferentes significados, dependendo do grupo que o utiliza.

\section{PONTOS A PARTIR DOS QUAIS ESTUDAR O CONSUMO}

Os Estudos de Consumo são recentes no campo da Comunicação; não existem teorias que possam ser aplicadas para podermos analisá-los. No entanto, gostaríamos de partir de alguns pontos que foram propostos por Everardo Rocha $^{12}$ e por Canclini ${ }^{13}$.

Os pontos abordados por Rocha para se estudar o consumo são: em primeiro lugar, enxergar o consumo como um sistema de significação; em segundo lugar, como um código pelo qual "são traduzidas muitas das nossas relações sociais"14; em terceiro, como código que permite a classificação de pessoas e coisas e, por fim, estudar os meios de comunicação como instância que viabiliza o consumo.

Canclini aborda seis pontos para se pensar o consumo: um é o "consumo como lugar de reprodução da força de trabalho e expansão do capital" "15; o segundo é "o consumo como o lugar em que as classes sociais e grupos competem pela apropriação do produto social"16; o terceiro é "o consumo como lugar de diferenciação social"17; o quarto, "o consumo como sistema de integração e comunicação"18; o quinto é "o consumo como cenário de objetivação dos desejos" $" 19$ e o sexto, "o consumo como processo ritual" ${ }^{20}$.

Concluímos que não há a necessidade de abordar todos os pontos, apenas aqueles que estão mais próximos da pesquisa que se deseja realizar. Para os Estudos de Telenovela, por exemplo, selecionamos três pontos ${ }^{21}$ que seriam interessantes abordar. Estes foram utilizados em pesquisa recente ${ }^{22}$ para analisar duas telenovelas: Duas Caras (Rede Globo) e A Outra (TVI - Portugal):

1) O consumo como forma de diferenciação e inclusão social.

2) O consumo como realização dos desejos.

3) O consumo como processo ritual.
12. ROCHA, Everardo. Culpa e prazer: imagens do consumo na cultura de massa. Comunicação e práticas de consumo, São Paulo, v. 2, n. 3, mar. 2005.

13. GARCÍA CANCLI$\mathrm{NI}$, Néstor. Los estudios sobre comunicación y consumo: el trabajo interdisciplinario en tiempos neoconservadores (Os estudos sobre comunicação e consumo: o trabalho interdisciplinar em tempos neoconservadores). Diálogos, Peru, n. 74, p. 1-9, mayo-agosto 2007.

14. ROCHA, op. cit., p. 136.

15. GARCÍA CANCLINI, Los estudios sobre comunicación..., cit., p. 3 .

16. Ibid., p. 4.

17. Ibid.

18. Ibid.

19. Ibid., p. 5.

20. Ibid., p. 6.

21. Os quatro pontos são uma mescla dos pontos propostos por Canclini e por Everardo Rocha.

22. ABRÃO, Maria Amélia Paiva. Comunicação, recepção e consumo: as manifestações culturais e sua influência na formação das identidades. Um estudo sobre as telenovelas Duas Caras (brasileira) e A Outra (portuguesa). São Paulo: ESPM, 2010. 
Analisamos cenas de ambas as telenovelas, com núcleos familiares da classe alta e da classe média baixa, cenas do cotidiano, de processos rituais de despedida (velórios), de celebração (casamentos), inclusive cenas de merchandising comercial, entre outros. Ao longo de cada episódio íamos verificando como os objetos de consumo estavam inseridos no contexto da narrativa, quais significados eram atribuídos aos mesmos. E como o consumo poderia ser estudado naquelas cenas a partir de um ou mais dos pontos supracitados.

\section{O CONSUMO COMO FORMA DE DIFERENCIAÇÃO E INCLUSÃO SOCIAL}

A sociedade contemporânea é fluida, movimenta-se e transforma-se incessantemente, e com ela são criadas e reformuladas diversas identidades. O sujeito desta sociedade encontra-se em uma busca permanente por identidades, que tanto o farão sentir integrante de um determinado grupo quanto o distinguirão de outros. Nessa busca constante por inclusão e diferenciação encontram-se os bens materiais/simbólicos que, munidos de significados, facilitarão o contato social do sujeito com os grupos.

Através dos objetos, ou melhor, do consumo, o indivíduo se encontrará em um determinado grupo e, ao mesmo tempo, se distanciará da imagem ou dos grupos dos quais não deseja participar. Por isso, afirmamos que o consumo, como parte das identidades, é uma forma de inclusão e diferenciação social.

O consumo permite um exercício de classificação do mundo que nos cerca a partir de si mesmo e, como é próprio de códigos abertos, é sempre capaz de incluir novos elementos. O consumo é inclusivo em, pelo menos, dois sentidos: de um lado, os novos produtos e serviços que a ele se agregam e são articulados aos demais e, do outro, as identidades e relações sociais definidas e negociadas em larga medida, a partir de sua inclusão no sistema ${ }^{23}$.

Não nos podemos nos esquecer de que o significado dado a um objeto não é o mesmo em todos os grupos ou ocasiões. Podemos dizer, pois, que os grupos são reconhecidos a partir de padrões de consumo. Sendo assim, o modo como consumimos é estruturado a partir dos grupos aos quais pertencemos.

Para falar de disBARROS, Carla Entr mundos distintos: no tas sobre comunicação e consumo em um grupo social. In: BACCEGA, Maria Aparecida (Org.). Comunicação e culturas do consumo. São Paulo: Atlas, 2008. p. 198.

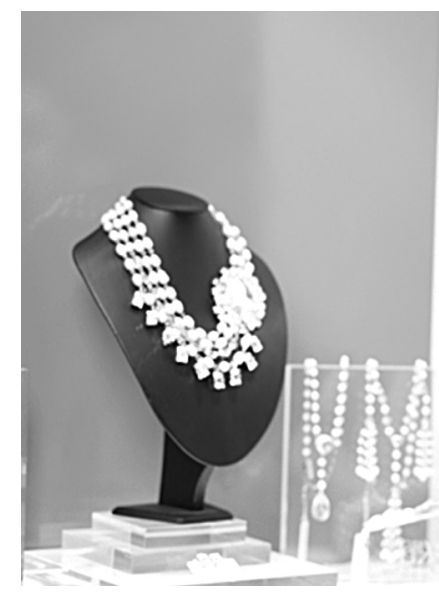

O consumo, embora seja um ato individual, é realizado por meio da socialização. 
"o princípio gerador de práticas objetivamente classificáveis e ao mesmo tempo sistema de classificação de tais práticas" ${ }^{24}$. Ou seja, cada grupo possui seu habitus, que é o princípio organizador de práticas e de representações. Este será reconhecido apenas pelos sujeitos que possuem capacidade de entendê-lo, isto é, "dotados de percepção e de apreciação necessários para identificar, interpretar e avaliar seus traços" ${ }^{25}$. Sendo assim, através do habitus de um grupo, podemos conhecer o que o diferencia dos demais e qual o seu estilo de vida.

O consumo, embora seja um ato individual, é realizado por meio da socialização do sujeito com determinados grupos, que se diferenciam a partir dos produtos utilizados/consumidos.

Em suma, o consumo se relaciona à necessidade de distinção. O que consumimos é resultado de nossas interações sociais com os grupos aos quais pertencemos, não são escolhas individuais. Como diria Slater,

[...] o consumo não pode ser reduzido a "sujeitos que usam objetos", porque os dois não são independentes; estão integralmente ligados, quer o saibam, quer não. O mundo das coisas é realmente a cultura em sua forma objetiva, é a forma que os seres humanos deram ao mundo através de suas práticas mentais e materiais; ao mesmo tempo, as próprias necessidades humanas evoluem e tomam forma através de coisas de que dispõem ${ }^{26}$.

\section{O CONSUMO COMO REALIZAÇÃO DOS DESEJOS}

Alguns pesquisadores ${ }^{27}$ apontam que o consumo era visto como uma atividade coletiva, isto é, comprávamos produtos para partilhar com a família, com os amigos. Ele estava ligado mais à satisfação, ou seja, se estávamos com fome, procurávamos algo para comer; claro que de acordo com as necessidades sociais criadas pelo grupo ao qual pertencíamos. No entanto, "o consumismo de hoje não diz respeito [apenas] à satisfação das necessidades [...] mas ao desejo - entidade muito mais volátil e efêmera" ${ }^{28}$.

Atualmente, o consumo é tido como um ato individual, no sentido em que o sujeito tem a possibilidade de escolher o que deseja comprar e não irá, necessariamente, compartilhar com outras pessoas; busca o prazer através do consumo, seja ele bens materiais, ou não. Já dizia Campbell que os objetos possuem utilidade ou capacidade de proporcionar satisfação. É, nesse sentido, um atributo intrínseco das coisas reais:

[...] o alimento pode aliviar a fome, a roupa proporciona calor [...]. O prazer, por outro lado, não é uma propriedade intrínseca de qualquer objeto, mas um tipo de reação que os homens têm comumente, ao encontrar certos estímulos. [...] procurar prazer é expor-se a certos estímulos, na esperança de que estes detonarão uma resposta desejada dentro de si mesmo ${ }^{29}$.

Segundo Campbell ${ }^{30}$, o consumo está ligado ao self, isto é, à subjetividade. A nossa constante busca por novos produtos seria resultado de uma modificação do próprio self. Ao consumirmos estamos satisfazendo uma determinada emoção, e quanto maior for a intensidade da nossa reação perante um objeto, mais
24. BOURDIEU, Pierre. A distinção: crítica social do julgamento. São Paulo: Edusp, 2007. p. 162.

25. Ibid., p. 164

26. SLATER, op. cit., $p$ 104.

27. Colin Campbell e Zygmunt Bauman.

28. BAUMAN, Zygmunt. Modernidade líquida. Rio de Janeiro: Jorge Zahar, 2001. p. 88.

29. CAMPBELL, Colin A ética moderna e o espírito do consumismo moderno. Rio de Janeiro: Rocco, 2001. p. 91.

30. Id. Eu compro, logo sei que existo: as bases metafísicas do consumo moderno. In: BARBOSA, Lívia: CAMPBELL, Colin (Org.). Cultura, consumo e identidade. Rio de Janeiro: Editora FGV, 2006. 
31. GARCÍA CANCLINI, Los estudios sobre comunicación..., cit., p. 5.

32. MCCRACKEN, op. cit., p. 114.

33. DOUGLAS, Mary; ISHERWOOD, Baron. O mundo dos bens: para uma antropologia do consumo. Tradução de Plínio Dentzen. Rio de Janeiro: Editora UFRJ, 2004. p. 112. vivos e autênticos nos sentiremos. Desejamos vivenciar aquilo que imaginamos, e isso é possível a partir do consumo. No entanto, quando o produto ou serviço já produziu uma determinada emoção, ele não será capaz de reproduzi-la novamente, por isso recorreríamos a outros produtos.

Assim como Campbell, acreditamos que o sujeito se encontra em uma busca constante por novos prazeres, por novas emoções. E isto é acentuado a partir das múltiplas identidades. Cada identidade buscará um tipo de emoção para satisfazer os seus desejos, sejam eles materiais, ou não. Enfim, acreditamos que "o desejo não pode ser ignorado quando analisamos as formas de consumir"31.

\section{O CONSUMO COMO UM PROCESSO RITUAL}

Não é nosso objetivo nesse momento descrever todos os estudos sobre rituais, suas formas e utilidades. $\mathrm{O}$ que nos interessa é entender que os rituais são celebrações para fixar determinados significados na sociedade. Uma forma de fazer com que alguns significados perdurem por mais tempo em nosso cotidiano, já que, como dissemos anteriormente, a sociedade contemporânea está em constante mudança, na qual ou através da qual ou pela qual os significados são legitimados e ressignificados a todo momento.

Dessa forma, o ritual

[...] é um tipo de ação social dedicada à manipulação do significado cultural para propósitos de comunicação e categorização coletiva e individual. O ritual é uma oportunidade para afirmar, evocar, ou revisar símbolos e significados convencionais de ordem cultural ${ }^{32}$.

Todo e qualquer significado não é dado de forma individual, mas sim coletiva. Nós não conseguiríamos atribuir um significado a um determinado objeto sem que fosse aceito pelos grupos aos quais pertencemos. É através dos rituais que compartilhamos e legitimamos os significados que desejamos fixar em um grupo.

Para fixar estes significados se faz necessária a reprodução constante dos rituais, que são caracterizados por repetições, seja de palavras, de gestos, seja de símbolos. Estes nada mais são do que objetos, bens utilizados como forma de reforçar os significados atribuídos em uma cerimônia. Segundo Douglas e Isherwood, os

[...] rituais mais eficazes usam coisas materiais, e podemos supor que, quanto mais custosa a pompa ritual, tanto mais forte a intenção de fixar os rituais. Os bens, nessa perspectiva, são acessórios rituais; o consumo é um processo ritual cuja função primária é dar sentido ao fluxo incompleto dos acontecimentos ${ }^{33}$.

Quando falamos de rituais, logo nos vêm à cabeça as grandes cerimônias religiosas. Mas como nos lembra Slater, os rituais estão em toda parte, são formas de socialização. Para este autor, "comer é uma atividade que ocorre dentro de rituais de sociabilidade [...]. A atividade de consumir comida não o envolve [não envolve o sujeito] somente em termos de reprodução física, mas 
também de reprodução cultural" ${ }^{34}$. Ou seja, a forma como preparamos nossa comida está ligada à nossa cultura, assim como o ato de comer também envolve rituais culturais. Por exemplo, os árabes comem com as mãos, enquanto nós ocidentais comemos com talheres e os asiáticos com hashi. Esses rituais são repassados em nosso cotidiano de gerações em gerações.

Elizabeth Pleck fala do ritual familiar que "é uma performance repetitiva, que envolve vários membros da família, possuindo uma estrutura formal e comportamentos simbólicos (gestos, palavras ou ações). A estrutura formal possui uma ordem fixa, isto é, com começo, meio e fim"35.

Como vemos, é através dos rituais familiares que diversos significados culturais são repassados e fixados na sociedade, desde a forma como nos alimentamos até a importância em presentear os familiares/amigos em determinadas datas. Tudo é construído socialmente e isto ocorre no cotidiano da sociedade.

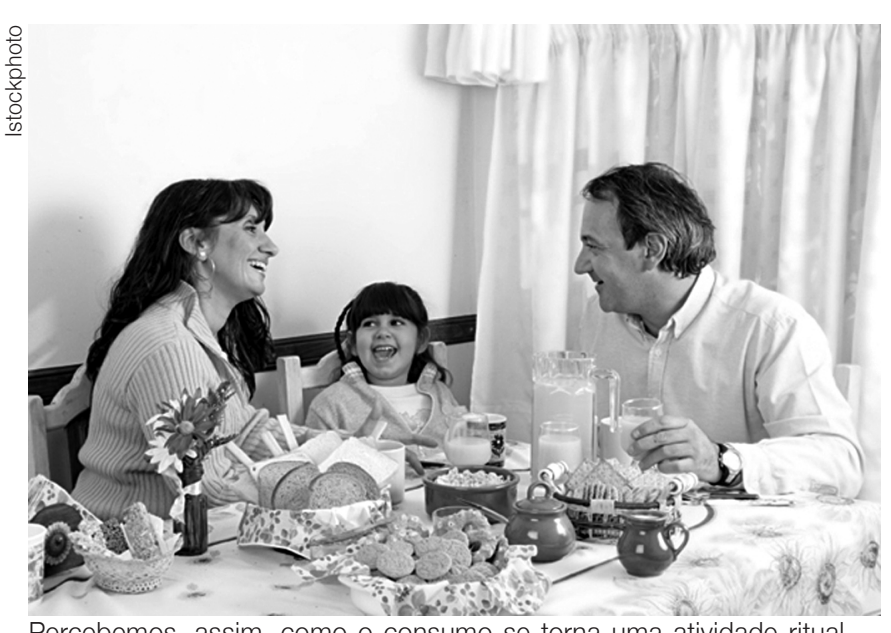

Os rituais nos ajudam a definir quem somos, além de assegurar a "continuidade familiar, do grupo e religiosa" ${ }^{36}$, já que lidamos "com um mundo em constante mudança" ${ }^{37}$.

Percebemos, assim, como o consumo se torna uma atividade ritual. E o mercado aproveita para comercializar esses rituais, ou seja, utiliza-se, principalmente, dos rituais familiares para promover a venda de determinados produtos através da propaganda, das telenovelas, entre outros. Como exemplo, podemos citar as cenas dos comerciais de margarina em que o produto sempre aparece no café da manhã (um ritual de sociabilidade) de uma família feliz e celebrando o desjejum. Muitas vezes o produto mal aparece, o que surge mesmo é o ritual. Os merchandisings nas telenovelas também são inseridos em rituais, justamente para dar significado ao produto anunciado, pois este, por si só, não tem valor algum. Como exemplo, citemos a telenovela Passione ${ }^{38}$, em que a personagem Clô Souza e Silva, considerada nova rica, desenvolveu um novo hábito logo que se mudou para o Jardim América, bairro nobre de São Paulo: tomar determinada marca de suco em seu café da manhã todos os dias. Ao ser inserido nas cenas de desjejum da família Souza e Silva, este produto adquire os significados pertencentes a esta família e ao seu grupo. O produto naquela mesa de café da manhã, com as falas dos personagens, ao redor dos demais objetos, absorve os significados que lhe são atribuídos - isolado não possui sentido, valor simbólico. Se colocado em outro núcleo da trama, o mesmo absorveria outros valores. Na família de Clô o suco apresentado adquire o significado de
34. SLATER, op. cit., p. 130-131.

35. PLECK, Elizabeth Hafkin. Celebrating the family: ethnicity, consumer culture and family rituals (Celebrando a família: etnia e rituais de cultura do consumo e da família). Massachusetts: Harvard University Press, 2000. p. 10.

36. Ibid., p. 20.

37. Ibid.

38. De Silvio de Abreu. Maio de 2010 a janeiro de 2011. 
uma bebida sofisticada, requintada, para ser degustada no desjejum. Antes de se mudar para o Jardim América, a personagem não sabia o que era isso, a bebida não pertencia ao seu cotidiano.

\section{CONSIDERAÇÕES FINAIS}

As relações dos estudos de Comunicação e Consumo são uma nova forma de apreender a cultura no campo da Comunicação.

Identificamos que para estudar o consumo a partir das telenovelas é interessante vê-lo como um processo ritual, em que os produtos são inseridos em rituais familiares reforçando valores e absorvendo significados.

Pode-se estudar o consumo como forma de diferenciação e inclusão social, em que um indivíduo se apropria de um bem para se incluir em um determinado grupo e ao mesmo tempo se diferenciar.

Por fim, vimos o consumo como realização dos desejos, ou seja, na sociedade contemporânea em que vivemos há uma constante busca do self, do eu, das identidades, que levam à busca de produtos como forma de realização dos desejos.

A partir desses pontos, pode-se estudar uma sociedade observando as manifestações do consumo apresentadas em uma telenovela, trazendo um novo olhar para o campo da Comunicação.

\section{REFERÊNCIAS BIBLIOGRÁFICAS}

ALONSO, Luiz Enrique. La era del consumo (A era do consumo). Madrid: Siglo XXI, 2006.

BAUMAN, Zygmunt. Modernidade líquida. Rio de Janeiro: Jorge Zahar, 2001.

BOURDIEU, Pierre. A distinção: crítica social do julgamento. São Paulo: Edusp, 2007.

CAMPBELL, Colin. Eu compro, logo sei que existo: as bases metafísicas do consumo moderno. In: BARBOSA, Lívia; CAMPBELL, Colin (Org.). Cultura, consumo e identidade. Rio de Janeiro: Editora FGV, 2006.

A ética moderna e o espírito do consumismo moderno. Rio de Janeiro: Rocco, 2001.

CANCLINI, Nestor G. Los estudios sobre comunicación y consumo: el trabajo interdisciplinario em tiempos neoconservadores (Os estudos sobre comunicação e consumo: o trabalho interdisciplinar em tempos neoconservadores). Diálogos, Peru, n. 74, mayo-agosto 2007.

Consumidores e cidadãos: conflitos multiculturais da globalização. Tradução de Maurício Santana Dias e Javier Rapp. 4. ed. Rio de Janeiro: Editora UFRJ, 1999. 
DOUGLAS, Mary; ISHERWOOD, Baron. O mundo dos bens: para uma antropologia do consumo. Tradução de Plínio Dentzen. Rio de Janeiro: Editora UFRJ, 2004.

MARX, Karl. Para a crítica da economia política. São Paulo: Abril Cultural, 1982.

MCCRACKEN, Grant. Cultura e consumo: novas abordagens ao caráter simbólico dos bens e das atividades de consumo. Tradução de Fernando Eugênio. Rio de Janeiro: Mauad, 2003.

PLECK, Elizabeth Hafkin. Celebrating the family: ethnicity, consumer culture and family rituals (Celebrando a família: etnia e rituais de cultura do consumo e da família). Massachusetts: Harvard University Press, 2000.

ROCHA, Everardo. Culpa e prazer: imagens do consumo na cultura de massa. Comunicação e práticas de consumo, São Paulo, v. 2, n. 3, mar. 2005.

; BARROS, Carla. Entre mundos distintos: notas sobre comunicação e consumo em um grupo social. In: BACCEGA, Maria Aparecida (Org.). Comunicação e culturas do consumo. São Paulo: Atlas, 2008.

SLATER, Don. Cultura do consumo \& modernidade. Tradução de Dinah de Abreu Azevedo. São Paulo: Nobel, 2002.

\section{Endereço eletrônico}

BACCEGA, Maria Aparecida. Inter-relações comunicação e consumo na trama cultural: o papel do sujeito ativo. Animus: revista do Programa de Pós-Graduação da UFSM, v. 15, p. 4, 2009. Disponível em: <http://w3.ufsm.br/animus/ animus_2009-1_art06.html>. Acesso em: 8 out. 2010. 


\title{
Comunicação
}

\section{Diálogo dos saberes na cultura midiática}

\author{
Joana Puntel recupera o pensamento da Igreja Católica sobre comunicação \\ e presta importante contribuição aos agentes de pastoral e responsáveis \\ pela área no âmbito da instituição.
}

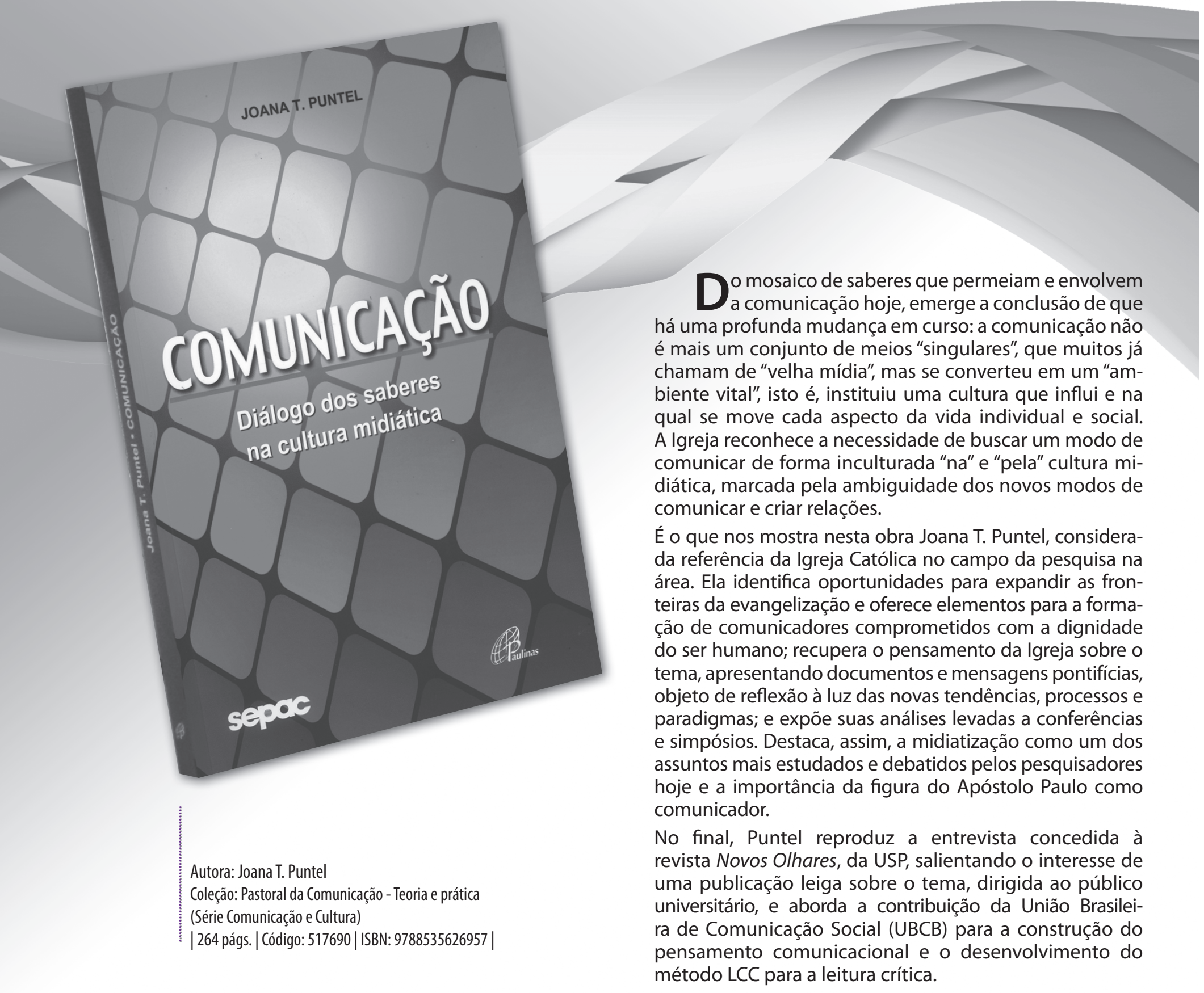

\section{À venda na Rede Paulinas de Livrarias Se preferir, ligue 08007010081 ou acesse www.paulinas.org.br/loja}

